\title{
Sistem Pendukung Keputusan Rekrutmen Karyawan dengan Multi Kriteria menggunakan Metode AHP dan SAW
}

\author{
Nabilah Yadzhan Fadilah ${ }^{\mathrm{a} 1}$, Safitri Juanita ${ }^{\mathrm{a} 2}$, Pamela Larasati ${ }^{\mathrm{b} 3}$ \\ ${ }^{a}$ Program Studi Sistem Informasi, Fakultas Teknologi Informasi, Universitas Budi Luhur \\ ${ }^{b}$ Magister Ilmu Komputer, Fakultas Teknologi Informasi, Universitas Budi Luhur \\ Jl. Ciledug Raya, Petukangan Utara, Pesanggrahan, Jakarta Selatan, DKI Jakarta 12260, Indonesia \\ ${ }^{1}$ nabilahyfegmail.com \\ ${ }^{2}$ Safitri.juanita@budiluhur.ac.id \\ 3pamela.larasati@gmail.com
}

\begin{abstract}
Abstrak
Badan Pusat Statistik (BPS) mencatat pengangguran tahun 2019 meningkat menjadi 50 ribu orang dan pada tahun 2020 bertambah pengangguran sebanyak 60 ribu orang. Meningkatnya angka pengangguran berkorelasi dengan meningkatnya kuantitas pelamar pekerjaan pada perusahaan, sehingga diperlukan sistem pendukung keputusan (SPK) yang dapat mempermudah perusahaan untuk melakukan rekrutmen karyawan. Masalah penelitian ini yaitu saat ini, PT. Karya Usaha Aneka Terjaya melakukan proses penilaian rekrutmen karyawan secara manual sehingga hasil keputusan membutuhkan waktu yang cukup lama karena banyaknya pelamar pekerjaan, terdapat subjektifitas dalam melakukan penilaian, dan semua kriteria pada proses rekrutmen karyawan belum memiliki pembobotan. Dampak dari masalah tersebut adalah proses penilaian karyawan menjadi kurang tepat serta tidak adanya perangkingan sehingga manager membutuhkan waktu dalam mengambil keputusan. Tujuan penelitian adalah merancang aplikasi SPK menggunakan multi kriteria dengan metode Analytical Hierarchy Process (AHP) dan Simple Additive Weighting (SAW) yang nantinya akan digunakan untuk membantu manager dalam mengambil keputusan pada proses rekrutmen karyawan. Metode Penelitian yang digunakan adalah metode studi kasus yang dilakukan pada PT. Karya Usaha Aneka Terjaya, multi kriteria yang digunakan pada penelitian ini adalah interview (komunikasi, kesiapan kerja, kesopanan), psikotes(ketelitian, kepribadian), dan kompetensi(skill, pengetahuan). Metode untuk pembobotan kriteria menggunakan AHP dan perangkingan menggunakan SAW, aplikasi dibangun menggunakan PHP dan MySQL. Kesimpulannya pada penelitian ini adalah metode AHP dan SAW pada sistem penunjang keputusan rekrutmen karyawan dengan multi kriteria dapat mengurangi proses subjektifitas yang tinggi serta dapat menghasilkan nilai akhir yang akurat dalam penilaian pelamar pekerjaan, serta membantu perusahaan dalam proses perekrutan karyawan karena proses pendataan administrasi pelamar pekerjaan dilakukan secara online. Selain itu Perhitungan serta keluaran sistem untuk menampilkan nilai seluruh pelamar pekerjaan dilakukan dengan cepat sehingga pemegang keputusan dapat menentukan pilihan dengan cepat dan tepat.
\end{abstract}

Kata kunci: Sistem Pendukung Keputusan (SPK), Analytical Hierarchy Process (AHP), Simple Additive Weighting (SAW), Rekrutmen Karyawan, Multi Kriteria

\section{Decision Support System for Employee Recruitment with Multi Criteria using AHP and SAW Methods}

\begin{abstract}
Badan Pusat Statistik (BPS) or Government-owned Central Bureau of Statistics noted that unemployment in 2019 increased to 50 thousand people and in 2020 the unemployment increased by 60 thousand people. The increase in unemployment rate correlates with the increasing quantity of job applicants at the company, so a decision support system (SPK) is needed which can make it easier for companies to recruit employees. The problem of this research is that currently, PT. Karya Usaha Aneka Terjaya conducts a manual employee recruitment assessment process so that the decision results take a long time due to the large number of job applicants, subjectivity in conducting assessments, and all criteria in the employee recruitment process do not have the weight of criteria. The impact of this problem is that the employee appraisal process becomes less precise and there is no ranking so that managers need time to make decisions. The research objective was to design a DSS application using multi criteria with Analytical Hierarchy Process (AHP) and Simple Additive
\end{abstract}


Weighting (SAW) methods which will later be used to assist managers in making decisions on the employee recruitment process. The research method used is a case study method conducted at PT. Karya Usaha Aneka Terjaya, the multi criteria used in this research are interview (communication, work readiness, politeness), psychological test (accuracy, personality), and competence (skill, knowledge). Methods for weighting criteria using AHP and ranking using SAW, applications built using PHP and MySQL. The conclusion in this study is that AHP and SAW methods in the decision support system for employee recruitment with multi criteria can reduce the high subjectivity process and can produce accurate final value in the assessment of prospective employees, as well as assist the company in the hiring process of employees because the applicant administration logging process is done online. In addition, calculation and output of the system to display the value of all applicants is done quickly so that the decision-makers can make choices quickly and appropriately.

Keywords: Decision Support System (DSS), Analytical Hierarchy Process (AHP), Simple Additive Weighting (SAW), Employee Recruitment, Multi Criteria

\section{PENDAhUluAN}

Badan Pusat Statistik (BPS) mencatat jumlah pengangguran di Indonesia meningkat menjadi 50 ribu orang per Agustus 2019 [1] dan dalam setahun terakhir (tahun 2020) pengangguran bertambah menjadi 60 ribu orang [2]. Melihat makin banyaknya pengangguran maka PT.Karya Usaha Aneka Terjaya yaitu perusahaan perdagangan umum yang telah berkembang menjadi perusahaan distribusi khusus untuk aksesoris pipa fitting yang berdiri sejak tahun 2016 ingin melakukan proses rekrutmen karyawan secara terkomputerisasi. Saat ini PT. Karya Usaha Aneka Terjaya melakukan proses rekrutmen karyawan rata-rata 2 (dua) kali dalam setahun dengan jumlah pelamar pekerjaan 50-60 orang, proses penilaian pada saat rekrutmen karyawan menggunakan multi kriteria yaitu penilaian saat psikotes, tes kompetensi dan wawancara. Proses rekrutmen karyawan tersebut masih memiliki beberapa masalah diantaranya masih adanya subjektifitas dalam proses penilaian pelamar pekerjaan dan proses penilaian membutuhkan waktu lama karena dilakukan secara manual sehingga mengakibatkan proses pengambilan keputusan menjadi lambat.

Dari permasalahan tersebut, maka diperlukan penelitian tentang Sistem Penunjang Keputusan (SPK) menggunakan multi kriteria dengan metode Analytical Hierarchy Process (AHP) dan Simple Additive Weighting (SAW) untuk membantu manager dalam mengambil keputusan cepat dan tepat pada proses rekrutmen karyawan.

Metode AHP biasa digunakan untuk memecahkan permasalahan yang multi kriteria karena menggunakan struktur hierarki yang terdiri dari gol atau tujuan, kriteria, subkriteria, dan alternatif [3]. Tahapan AHP adalah sebagai berikut [3]:

- Menentukan tujuan/sasaran

- Menyusun Kriteria/Subkriteria dan alternatif

- Menyusun Hirarki.

- Melakukan perhitungan perbandingan berpasangan.

- Melakukan perhitungan normalisasi dan pembobotan

- Menghitung Eigen

- Menghitung Consistency Index (CI) dan Consistency Ratio (CR)

- Menguji konsistensi CR, Jika $\mathrm{CR}=<0.1$ maka standar konsistensi bisa diterima namun jika belum maka lakukan perhitungan kembali tahap 4-7

Metode SAW sering juga dikenal dengan istilah metode penjumlahan terbobot [4]. Metode SAW digunakan untuk menghitung nilai akhir alternatif yaitu untuk memilih pelamar pekerjaan di PT. Karya Usaha Aneka Terjaya yang paling memenuhi kriteria. Keluaran yang nantinya dihasilkan adalah urutan nilai alternatif dari nilai tertinggi hingga alternatif dengan nilai terendah. Tahapan SAW adalah sebagai berikut [4]:

- Menentukan Kriteria-kriteria yang dijadikan acuan dalam pengambilan keputusan

- Menentukan rating kecocokan setiap kriteria pada setiap kriteria

- Membuat matriks keputusan berdasarkan kriteria, kemudian melakukan normalisasi matriks berdasarkan persamaan yang disesuaikan dengan jenis atribut sehingga diperoleh matriks ternormalisasi.

- Hasil akhir diperoleh dari proses perangkingan yaitu penjumlahan dari perkalian matrik ternormalisasi $\mathrm{R}$ dengan vektor bobot preferensi sehingga diperoleh nilai terbesar yang dipilih sebagai alternatif terbaik.

Penelitian terdahulu tentang Sistem Penunjang Keputusan untuk penerimaan karyawan dengan multi kriteria sudah banyak dilakukan, namun setiap penelitian memiliki perbedaan kriteria dalam pengambilan keputusan. Penelitian tersebut pada bab ini akan diuraikan menjadi 2 (dua) kelompok:

1) Penelitian dengan metode SAW : Penelitian [5] dengan 4 (empat) kriteria yaitu Kehadiran, SOP, Kedisiplinan dan Grooming, penelitian [6] dengan 3 (tiga) kriteria yaitu hasil tes, usia dan pengalaman kerja, dan penelitian [7] dengan 3(tiga) kriteria yaitu seleksi administrasi, test praktik komputer, test tertulis, Penelitian [8] menggunakan 5 (lima) kriteria yaitu tanggung jawab, sikap kerja, kedisiplinan, prestasi kerja dan kerjasama

2) Penelitian dengan metode AHP : Penelitian [9] dengan 4 (empat) kriteria yaitu pendidikan, performance tes, kemampuan berkomunikasi serta motivasi dan antusiasme, Penelitian [10] dengan 4 (empat) kriteria yaitu disiplin, kerjasama, tanggung jawab, kehadiran. Penelitian [11] dengan 5 (lima) kriteria, yaitu: pengetahuan, kemampuan, sikap, absensi, dan kerjasama dengan

Pada penelitian ini akan digunakan multi kriteria sebanyak 3 (tiga) kriteria yaitu interview, psikotes, dan kompetensi. Setiap kriteria memiliki sub kriteria yaitu interview (komunikasi, kesiapan kerja, kesopanan), psikotes (ketelitian dan kepribadian), dan kompetensi (skill, pengetahuan). Metode (AHP) digunakan untuk menentukan bobot pada banyak (multi) Kriteria dan metode SAW untuk menampilkan hasil nilai pelamar 
pekerjaan dalam bentuk ranking, dimana nilai terbesar akan dipilih sebagai alternatif terbaik

\section{METODOLOGI}

\section{A. Alur Penelitian}

Tahapan penelitian dimulai dari melakukan wawancara ke user atau pihak yang terlibat dalam pengambil keputusan. Pada penelitian studi kasus ini, dilakukan survey ke PT. Karya Usaha Aneka Terjaya, perusahaan distribusi pipa fitting yang beralamat di Jl.Pembangunan 3, Batu Ceper, Tangerang. Pada saat survey, peneliti melakukan wawancara kepada Manager Perusahaan untuk mengumpulkan data terkait kriteria yang akan digunakan untuk mengambil keputusan serta meminta beberapa dokumen yang terkait dengan sistem SPK.

Tahap yang dilakukan bersamaan dengan survey, wawancara serta analisis dokumen adalah melakukan studi literatur yaitu mengumpulkan dan membaca referensi seperti buku-buku dan publikasi yang berkaitan dengan SPK rekrutmen karyawan menggunakan AHP dan SAW. Metode pengembangan SPK menggunakan metode Waterfall [12] yang pada tahapannya dimulai dari tahap perencanaan yaitu proses identifikasi kebutuhan kemudian tahap analisis dan desain yaitu membuat perancangan sistem menggunakan diagram UML [12] berupa use case diagram, activity diagram, class diagram dan sequence diagram kemudian akan dilakukan pengolahan data dengan metode AHP dan SAW, tahap selanjutnya adalah desain yaitu membuat rancangan layar menggunakan Balsamiq Mockup, lalu melakukan koding sistem penunjang keputusan dengan bahasa Pemrograman PHP dan basis data MySQL dan yang terakhir dari tahap ini adalah evaluasi hasil implementasi. Alur Penelitian ditampilkan pada gambar 1 .

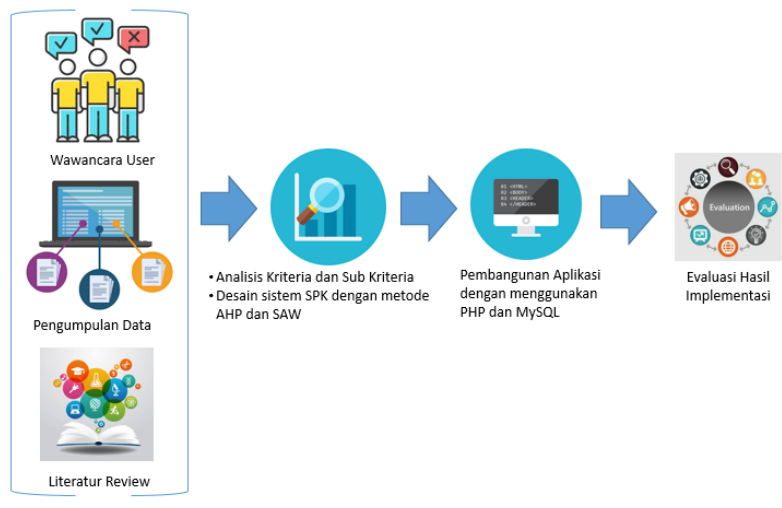

Gambar 1. Alur Penelitian

\section{B. Blok Diagram Proses SPK Rekrutmen Karyawan dengan multi kriteria menggunakan AHP dan SAW}

Proses dimulai dari menginput data pelamar pekerjaan, kemudian staff administrasi akan mulai menginput data kriteria dan data subkriteria, kemudian melakukan proses input nilai berdasarkan kriteria dan subkriteria sehingga akan dapat dihitung nilai bobot pada kriteria dan subkriteria dengan metode AHP, kemudian dari bobot tersebut akan diproses ranking nilai pelamar pekerjaan menggunakan metode SAW yang akan menghasilkan luaran berupa hasil keputusan rekrutmen karyawan. Alur blok diagram terdapat pada gambar 2 .

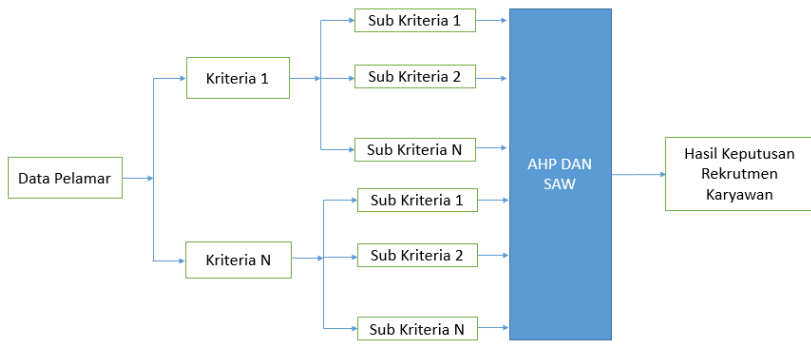

Gambar 2. Blok Diagram Proses SPK Rekrutmen Karyawan dengan multi kriteria menggunakan metode AHP dan SAW

\section{HASIL DAN PEMBAHASAN,}

\section{A. Analisis Masalah}

Pada tahap ini akan dilakukan proses analisis masalah pada proses pengambilan keputusan rekrutmen karyawan di PT.Karya Usaha Aneka Terjaya. Analisis masalah ditampilkan menggunakan Fishbone Diagram [13] pada gambar 3 .

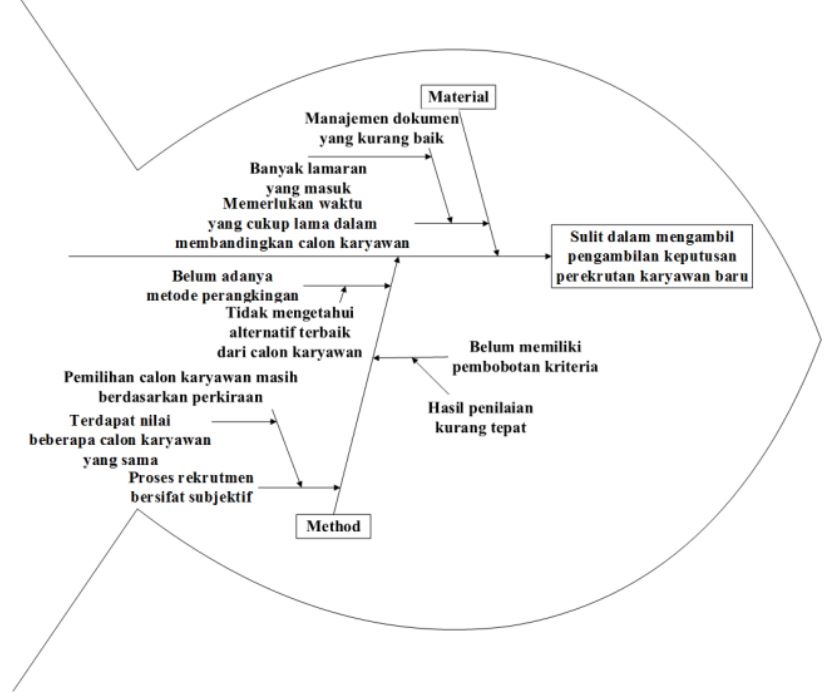

Gambar 3. Fishbone Diagram

\section{B. Proses Bisnis Berjalan}

Proses rekrutmen karyawan pada PT. Karya Usaha Aneka Terjaya dilakukan jika perusahaan membutuhkan karyawan. Proses rekrutmen karyawan dimulai saat Direktur menghubungi Manager melalui lisan, setelah itu manager membuat iklan dan menyebarkan iklan lowongan pekerjaan melalui media sosial. Pelamar pekerjaan yang tertarik dengan lowongan perkerjaan tersebut akan melamar pekerjaan dengan cara mengirimkan dokumen lamaran melalui email atau datang langsung ke PT. Karya Usaha Aneka Terjaya. Selanjutnya manager akan menyeleksi dokumen lamaran yang sesuai dengan iklan lowongan yang disebarkan. Setelah diseleksi maka pelamar pekerjaan yang sesuai kriteria akan dihubungi oleh manager untuk mengikuti beberapa tes dan wawancara. Pelamar pekerjaan yang sesuai kriteria dan lolos seleksi administrasi akan menerima informasi untuk 
hadir pada proses selanjutnya. kemudian pelamar pekerjaan atau pelamar pekerjaan akan datang ke PT.Karya Usaha Aneka Terjaya. Sebelum memulai tes, pelamar pekerjaan diberikan formulir karyawan oleh manager untuk diisi, setelah formulir lengkap diisi kemudian dilakukan tes psikotes, tes kompetensi, dan interview.

Setelah pelamar pekerjaan mengikuti tes, Manager dan Direktur melakukan diskusi dan penilaian untuk menyeleksi pelamar pekerjaan yang sesuai kriteria. Setelah mendapatkan pelamar pekerjaan yang sesuai, manager mengisi surat keterangan hasil tes. Jika pelamar pekerjaan diterima, manager akan menelpon pelamar pekerjaan yang lolos untuk memberitahu jika pelamar pekerjaan tersebut telah diterima sebagai karyawan PT. Karya Usaha Aneka Terjaya. Proses rekrutmen karyawan digambarkan menggunakan activity diagram pada gambar 4.

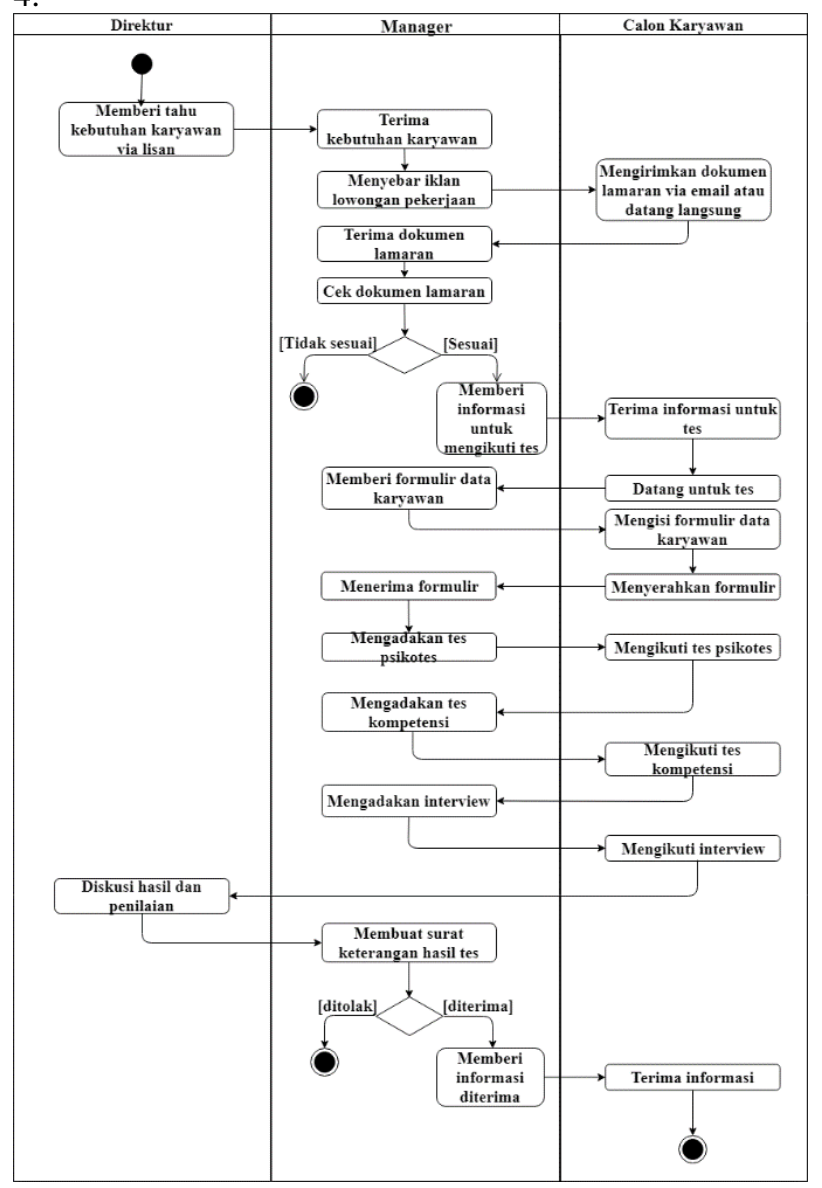

Gambar 4. Activity Diagram Proses Bisnis Berjalan Rekrutmen Karyawan

\section{Model Analytical Hierarchy Process (AHP)}

Tahapan AHP adalah sebagai berikut [3]:

1) Tahap 1 dan 2 menentukan tujuan/sasaran dan menyusun kriteria/subkriteria dan alternatif. Pada penelitian ini terdapat 3 (tiga) kriteria : interview, psikotes dan kompetensi. Setiap kriteria memiliki subkriteria.

2) Tahap 3 menyusun struktur hirarki perekrutan karyawan pada PT.Karya Usaha Aneka Terjaya yang terdapat pada gambar 5 .

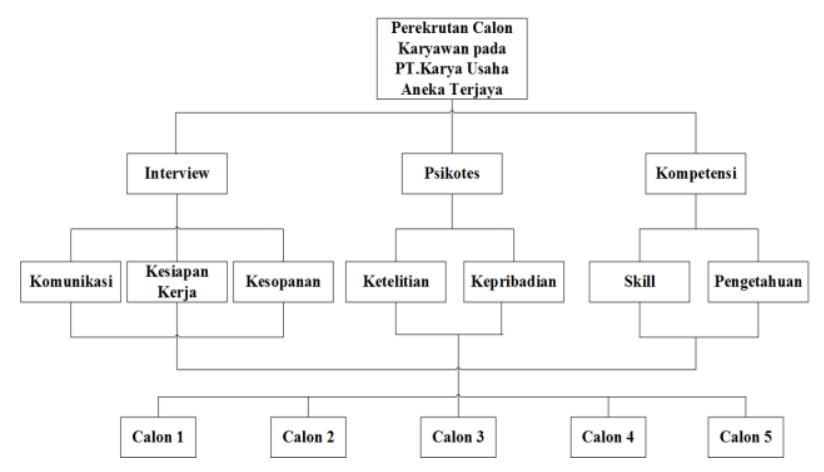

Gambar 5. Struktur Hirarki Kriteria Perekrutan Pelamar pekerjaan Pada PT.Karya Usaha Aneka Terjaya

3) Tahap 4 melakukan perhitungan perbandingan berpasangan.

Kriteria yang digunakan dalam proses rekrutmen karyawan pada PT.Karya Usaha Aneka Terjaya digambarkan pada Tabel I, dimana nilai interview 4 (empat) kali lebih penting dari nilai psikotes, nilai interview 3 (tiga) kali lebih penting dari nilai kompetensi, Nilai Psikotes 2 (dua) kali lebih penting dari Nilai Kompetensi.

TABEL I

MATRIKS PERBANDINGAN PER KRITERIA

\begin{tabular}{|c|c|c|c|}
\hline Kriteria & Interview & Psikotes & Kompetensi \\
\hline Interview & 1 & 4 & 3 \\
\hline Psikotes & $1 / 4$ & 1 & 2 \\
\hline Kompetensi & $1 / 3$ & $1 / 2$ & 1 \\
\hline
\end{tabular}

Dari Tabel I dilakukan penjumlahan matriks perbandingan yang ditampilkan pada Tabel II. Tabel III perhitungan nilai Eigen dilakukan dengan cara membagi nilai tiap baris dengan total jumlah pada tiap kolom.

TABEL II

Hasil PenJumlahan Matrik Pembobotan Kriteria

\begin{tabular}{|c|c|c|c|}
\hline Kriteria & Interview & Psikotes & Kompetensi \\
\hline Interview & 1 & 4 & 3 \\
\hline Psikotes & 0,25 & 1 & 2 \\
\hline Kompetensi & 0,33 & 0,25 & 1 \\
\hline Jumlah & $\mathbf{1 , 5 8}$ & $\mathbf{5 , 2 5}$ & $\mathbf{6}$ \\
\hline
\end{tabular}

TABEL III

PERHITUNGAN Nilai EIGEN

\begin{tabular}{|c|c|c|}
\hline Interview & Psikotes & Kompetensi \\
\hline $1 / 1,58=0,633$ & $4 / 5,25=0,762$ & $3 / 6=0,50$ \\
\hline $0,25 / 1,58=0,158$ & $1 / 5,25=0,190$ & $2 / 6=0,33$ \\
\hline $0,33 / 1,58=0,209$ & $0,25 / 5,25=0,048$ & $1 / 6=0,166$ \\
\hline
\end{tabular}

4) Tahap 5 dan 6 melakukan normalisasi dan pembobotan

Setiap baris pada Tabel III dijumlahkan kemudian dibagi dengan jumlah kriteria, Tahapan ini ada pada Tabel IV kolom kedua. Tahap 6 yaitu menghitung Eigen seperti yang disajikan pada Tabel IV kolom ketiga untuk mendapatkan nilai Eigen [9]. 
TABEL IV

NORMALISASI MATRIK KRITERIA

\begin{tabular}{|l|l|l|}
\hline Kriteria & Normalisasi matrik & Nilai Eigen \\
\hline Interview & $(0,633+0,762+0,50) / 3$ & 0,6316 \\
\hline Psikotes & $(0,158+0,190+0,33) / 3$ & 0,2260 \\
\hline Kompetensi & $(0,209+0,048+0,166) / 3$ & 0,1410 \\
\hline
\end{tabular}

5) Tahap 7 Menghitung Consistency Index (CI) dan Consistency Ratio (CR).

Berdasarkan hasil yang ditampilkan pada Tabel II dan Tabel IV maka akan dihitung nilai lamda maksimum [9]

$\lambda$ maks $=(1,58 \times 0,632)+(5,25 * 0,226)+(6 * 0,141)$

$=0,99856+1,1865+0,846$

$=3,03106$

$\mathrm{CI}=\underline{(\lambda \operatorname{maks}-\mathrm{n})}$

$$
\begin{aligned}
& =\frac{3,03106-3}{3-1} \\
& =\frac{0,03106}{2} \\
& =0,01553
\end{aligned}
$$

Jika $n=3$ maka Nilai RI=0,58 merujuk pada jurnal Saaty [14]

$$
\begin{aligned}
\mathrm{CR} & =\underline{\mathrm{CI}} \\
& =\underline{\mathrm{RI}} \\
& 0,01553 \\
& =0,0268
\end{aligned}
$$

6) Tahap 8 atau tahap terakhir dari AHP adalah menguji nilai $C R$.

Karena $\mathrm{CR}<0.1$ maka perbandingan konsisten. Dari hasil perhitungan di atas menunjukan bahwa kriteria:

- Interview memiliki bobot tertinggi yaitu 0,632

- Psikotes memiliki bobot tertinggi kedua yaitu 0,226

- Kompetensi memiliki bobot ketiga yaitu 0,141

Setelah dihitung bobot dari 3(tiga) kriteria, maka sekarang dilakukan bobot subkriteria dari masing-masing kriteria dimana:

- Komunikasi 4 (empat) kali lebih penting dari Kesiapan Kerja.

- Komunikasi 6 (enam) kali lebih penting dari Kesopanan.

- Kesiapan Kerja 4 (empat) kali lebih penting dari Kesopanan.

- Kepribadian 7 (tujuh) kali lebih penting dari Ketelitian.

- Skill 5 (lima) kali lebih penting dari Pengetahuan Penjelasan di atas, digambarkan pada Tabel V:

TABEL V

MATRIKS PERBANDINGAN SUBKRITERIA INTERVIEW

\begin{tabular}{|c|c|c|c|}
\hline Kriteria & Komunikasi & Kesiapan Kerja & Kesopanan \\
\hline Komunikasi & $1 / 1$ & $4 / 1$ & $6 / 1$ \\
\hline Kesiapan Kerja & $1 / 4$ & $1 / 1$ & $4 / 1$ \\
\hline Kesopanan & $1 / 6$ & $1 / 4$ & $1 / 1$ \\
\hline
\end{tabular}

TABEL VI

MATRIKS PERBANDINGAN SUBKRITERIA PSIKOTES

\begin{tabular}{|c|c|c|}
\hline Kriteria & Ketelitian & Kepribadian \\
\hline Ketelitian & $1 / 1$ & $1 / 7$ \\
\hline Kepribadian & $7 / 1$ & $1 / 1$ \\
\hline
\end{tabular}

TABEL VII

MATRIKS PERBANDINGAN SUBKRITERIA KOMPETENSI

\begin{tabular}{|c|c|c|}
\hline Kriteria & Skill & Pengetahuan \\
\hline Skill & $1 / 1$ & $5 / 1$ \\
\hline Pengetahuan & $1 / 5$ & $1 / 1$ \\
\hline
\end{tabular}

Proses perhitungan bobot menggunakan AHP untuk subkriteria (pada Tabel V-VII) sama seperti proses perhitungan kriteria (Tabel II-IV) sehingga didapatkan nilai bobot pada Tabel VIII-X.

TABEL VIII

NILAI EIGEN SUBKRITERIA INTERVIEW

\begin{tabular}{|c|c|}
\hline Kriteria & Nilai Eigen \\
\hline Komunikasi & 0,6896 \\
\hline Kesiapan Kerja & 0,2327 \\
\hline Kesopanan & 0,0777 \\
\hline
\end{tabular}

TABEL IX

NILAI EIGEN SUBKRITERIA KOMPETENSI

\begin{tabular}{|c|c|}
\hline Kriteria & Nilai Eigen \\
\hline Ketelitian & 0,1250 \\
\hline Kepribadian & 0,8750 \\
\hline
\end{tabular}

TABEL X

NiLAi EIGEN SUBKRITERIA PSIKOTES

\begin{tabular}{|c|c|}
\hline Kriteria & Nilai Eigen \\
\hline Skill & 0,8333 \\
\hline Pengetahuan & 0,1667 \\
\hline
\end{tabular}

Proses menghitung nilai CI pada subkriteria sama seperti proses perhitungan CI pada kriteria sehingga menghasilkan nilai $\mathrm{CI}=0,0549$ kemudian menghitung nilai untuk $n=3$ maka Nilai $\mathrm{RI}=0,58$ merujuk pada jurnal Saaty [14]

$$
\begin{aligned}
\mathrm{CR}= & 0,0549 \\
& 0,58 \\
= & 0,0946
\end{aligned}
$$

karena $\mathrm{CR}<0.1$ maka perbandingan konsisten.

\section{Model Keputusan dengan Simple Additive Weighting $(S A W)$}

Terdapat 2 atribut dalam metode SAW yaitu benefit dan cost [4] yang digambarkan pada tabel XI-XIV. Kemudian tahap awal adalah menghitung bobot pada kriteria dan subkriteria yang akan digunakan untuk rekrutmen karyawan, dimana pada penelitian ini terdapat 3 (tiga) kriteria yaitu kriteria interview dengan subkriteria komunikasi, kesiapan kerja, dan kesopanan (terdapat pada Tabel XII), nilai psikotes dengan subkriteria ketelitian dan kepribadian (terdapat pada Tabel XIII) dan nilai kompetensi dengan subkriteria skill dan pengetahuan (terdapat pada Tabel XIV).

\section{TABEL XI}

PENGGOLONGAN DAN BOBOT KRITERIA

\begin{tabular}{|l|l|l|l|}
\hline Kriteria & Benefit & Cost & Bobot \\
\hline Interview & $\sqrt{ }$ & - & $63 \%$ \\
\hline Psikotes & $\sqrt{ }$ & - & $23 \%$ \\
\hline Kompetensi & $\sqrt{ }$ & - & $14 \%$ \\
\hline
\end{tabular}


TABEL XII

PENGGOLONGAN DAN Bobot SUB KRITERIA INTERVIEW

\begin{tabular}{|c|c|c|c|}
\hline Subkriteria & Benefit & Cost & Bobot \\
\hline Komunikasi & $\sqrt{ }$ & - & $63 \%$ \\
\hline Kesiapan Kerja & $\sqrt{ }$ & - & $23 \%$ \\
\hline Kesopanan & $\sqrt{ }$ & - & $14 \%$ \\
\hline
\end{tabular}

TABEL XIII

PENGGOLONGAN DAN BOBOT SUB KRITERIA PSIKOTES

\begin{tabular}{|c|c|c|c|c|}
\hline Subkriteria & Benefit & Cost & Bobot & \\
\hline Ketelitian & $\sqrt{ }$ & - & $12,5 \%$ & \\
\hline Kepribadian & $\sqrt{ }$ & - & $87,5 \%$ & \\
\hline
\end{tabular}

TABEL XIV

PENGGOLONGAN DAN BoBOt SUB KRITERIA KoMPETENSI

\begin{tabular}{|c|c|c|c|}
\hline Subkriteria & Benefit & Cost & Bobot \\
\hline Skill & $\sqrt{ }$ & - & $83 \%$ \\
\hline Pengetahuan & $\sqrt{ }$ & - & $17 \%$ \\
\hline
\end{tabular}

Setelah mengetahui nilai bobot pada kriteria dan subkriteria, maka tahap selanjutnya adalah menentukan nilai alternatif masing-masing subkriteria dengan mengambil sampel pada populasi pelamar pekerjaan seperti yang digambarkan pada Tabel XV-XVII dengan nilai tertinggi untuk penilaian pada tiap subkriteria yaitu 100.

TABEL XV

NILAI ALTERNATIF SUBKRITERIA INTERVIEW

\begin{tabular}{|c|c|c|c|}
\hline \multirow{2}{*}{ Alternatif } & \multicolumn{3}{|c|}{ Subkriteria Interview } \\
\cline { 2 - 4 } & Komunikasi & Kesiapan Kerja & Kesopanan \\
\hline Samuel & 90 & 85 & 100 \\
\hline Novita S & 83 & 78 & 90 \\
\hline Imelda M & 92 & 100 & 87 \\
\hline Al Vanesh & 60 & 70 & 75 \\
\hline Arum R & 100 & 80 & 85 \\
\hline
\end{tabular}

TABEL XVI

NILAI ALTERNATIF SUBKRITERIA PSIKOTES

\begin{tabular}{|c|c|c|}
\hline \multirow{2}{*}{ Alternatif } & \multicolumn{2}{|c|}{ Subkriteria Psikotes } \\
\cline { 2 - 3 } & Ketelitian & Kepribadian \\
\hline Samuel & 75 & 89 \\
\hline Novita Sari & 90 & 100 \\
\hline Imelda M & 85 & 90 \\
\hline Al Vanesh & 77 & 75 \\
\hline Arum Rosma & 93 & 95 \\
\hline
\end{tabular}

TABEL XVII

NILAI ALTERNATIF SUBKRITERIA KOMPETENSI

\begin{tabular}{|c|c|c|}
\hline \multirow{2}{*}{ Alternatif } & \multicolumn{2}{|c|}{ Subkriteria Kompetensi } \\
\cline { 2 - 3 } & Skill & Pengetahuan \\
\hline Samuel & 65 & 85 \\
\hline Novita Sari & 83 & 90 \\
\hline Imelda M & 75 & 95 \\
\hline Al Vanesh & 100 & 92 \\
\hline Arum Rosma & 60 & 70 \\
\hline
\end{tabular}

Setelah sampel ditentukan dan diberikan penilaian pada setiap subkriteria, maka tahapan SAW selanjutnya dapat dilihat pada gambar 6. Tahapan dimulai dari proses perhitungan normalisasi matriks subkriteria kemudian proses perangkingan dengan bobot subkriteria dari metode AHP jika subkriteria masih ada maka akan dilakukan perulangan kedua proses tersebut hingga selesai. setelah selesai maka proses selanjutnya adalah proses perhitungan matriks kriteria dan proses terakhir adalah proses perangkingan dengan bobot kriteria dari metode AHP.

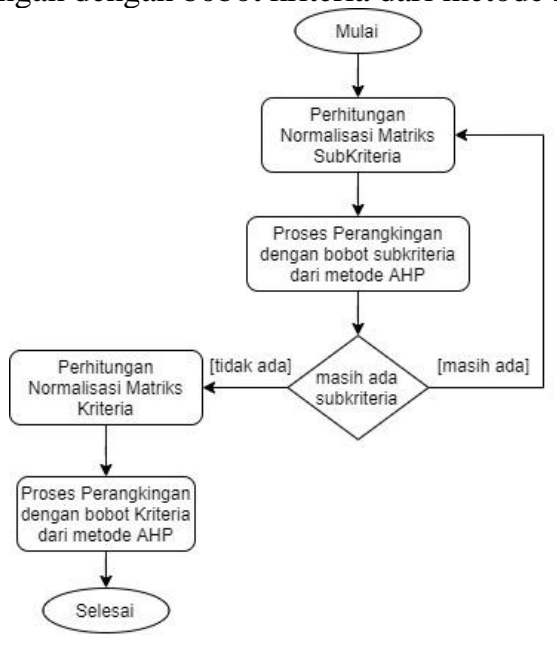

Gambar 6. Tahapan Proses Metode SAW

Tahapan-tahapan pada gambar 6 adalah sebagai berikut:

1) Perhitungan Normalisasi Matriks Subkriteria

Metode SAW membutuhkan proses normalisasi matriks keputusan (X) ke suatu skala yang dapat diperbandingkan dengan semua rating alternatif yang ada [6]. Rumus yang digunakan untuk menghitung normalisasi matriks keputusan terdapat pada (3)

$$
\mathrm{R}_{\mathrm{ij}}=\left\{\begin{array}{c}
\frac{x_{i j}}{\operatorname{Max} x_{i j}} \text { jika } j \text { adalah atribut keuntungan (benefit) } \\
\frac{\text { Min } x_{i j}}{x_{i j}} \text { jika } j \text { adalah atribut biaya }(\text { Cost })
\end{array}\right\}
$$

Keterangan:

$r_{\mathrm{ij} j} \quad=$ nilai rating kinerja ternormalisasi

$X_{i j} \quad=$ nilai atribut yang dimiliki dari setiap kriteria

$\operatorname{Max}_{i} X_{i j}=$ nilai terbesar alternatif dari setiap kriteria $\mathrm{i}$

$\operatorname{Min}_{\mathrm{i}} X_{\mathrm{ij}}=$ nilai terkecil alternatif dari setiap kriteria $\mathrm{i}$

Benefit $=$ jika nilai terbesar yang terbaik $(\mathrm{j})$

Cost $=$ jika nilai terkecil yang terbaik $(\mathrm{j})$

Contoh Perhitungan Normalisasi Matriks Subkriteria menggunakan rumus (3):

TABEL XVIII

SimULASI PENILAIAN PADA SUBKRITERIA KOMUNIKASI

\begin{tabular}{|c|c|}
\hline Alternatif & Komunikasi \\
\hline Samuel & 90 \\
\hline Novita S & 83 \\
\hline Imelda M & 92 \\
\hline Al Vanesh & 60 \\
\hline Arum R & 100 \\
\hline
\end{tabular}

Berdasarkan nilai alternatif pada kriteria Interview di Tabel XV, maka diambil salah satu contoh perhitungan pada subkriteria komunikasi yang terlihat pada Tabel XVIII. Simulasi perhitungan sesuai rumus (3) adalah sebagai berikut:

Normalisasi Matriks dengan rumus (3)

$$
\begin{aligned}
& \mathrm{R} 11= \\
& 90 \\
& =\underline{90}=0,900 \\
& \operatorname{Max}(90,83,92,60,100) \quad \frac{90}{100} \\
& \mathrm{R} 21=\frac{83}{\operatorname{Max}(90,83,92,60,100)}=\frac{83}{100}=0,8300
\end{aligned}
$$




$$
\begin{aligned}
& \mathrm{R} 31=\frac{92}{\operatorname{Max}(90,83,92,60,100)}=\frac{92}{100}=0,9200 \\
& \mathrm{R} 41=\frac{60}{\operatorname{Max}(90,83,92,60,100)}=\frac{60}{100}=0,6000 \\
& \mathrm{R} 51=\frac{100}{\operatorname{Max}(90,83,92,60,100)}=\frac{100}{100}=0,1000
\end{aligned}
$$

Semua nilai yang terdapat pada Tabel XV dihitung seperti contoh di atas, kemudian hasil akhir dari perhitungan normalisasi matriks pada subkriteria interview ditampilkan pada Tabel XIX.

TABEL XIX

NILAI MATRIKS NORMALISASI SUBKRITERIA INTERVIEW

\begin{tabular}{|c|c|c|c|}
\hline Alternatif & Komunikasi & Kesiapan kerja & Kesopanan \\
\hline Samuel & 0,9000 & 0,8500 & 1,0000 \\
\hline Novita S & 0,8300 & 0,7800 & 0,9000 \\
\hline Imelda M & 0,9200 & 1,0000 & 0,8700 \\
\hline Al Vanesh & 0,6000 & 0,7000 & 0,7500 \\
\hline Arum R & 1,0000 & 0,8000 & 0,8500 \\
\hline Bobot & 0,6896 & 0,2327 & 0,0777 \\
\hline
\end{tabular}

2) Proses Perangkingan dengan Bobot Sub Kriteria dari Metode AHP

Pada tahap selanjutnya akan dilakukan proses perangkingan dengan nilai pada Tabel XIX, proses perhitungan menggunakan bobot yang telah dihitung menggunakan metode AHP pada Tabel VIII. Ilustrasi proses perhitungan dengan sampel 5 (lima) pelamar pekerjaan adalah sebagai berikut:

Samuel $=\{(0,9000 \times 0,6896)+(0,8500 \times 0,2327)+(1,0000 \times 0,0$ $777)\}=0.6206+0.1978+0.0777=0.8961$

Novita $=\{(0,8300 \times 0,6896)+(0,7800 \times 0,2327)+(0,9000 \times 0,0$ $777)\}=0.5724+0.1815+0.0699=0.8238$

Imelda $=\{(0,9200 \times 0,6896)+(1,0000 \times 0,2327)+(0,8700 \times 0,0$

777) $\}=0,6344+0,2327+0,0676=0,9347$

Vanesh $=\{(0,6000 \times 0,6896)+(0,7000 \times 0,2327)+(0,7500 \times 0,0$

777) $\}=0.4138+0.1629+0.0582=0.6349$

Arum $=\{(1,0000 \times 0,6896)+(0,8000 \times 0,2327)+(0,8500 \times 0,07$

77) $\}=0.6896+0.1862+0.0660=0.9418$

Proses perhitungan nilai normalisasi matriks subkriteria pada Tabel XVI dan XVII dilakukan sama seperti proses sebelumnya (poin D.1) sehingga menghasilkan nilai pada Tabel XX dan Tabel XXI.

TABEL XX

NILAI MATRIKS NORMALISASI SUBKRITERIA PSIKOTES

\begin{tabular}{|l|l|l|}
\hline Alternatif & Ketelitian & Kepribadian \\
\hline Samuel & 0,8065 & 0,8900 \\
\hline Novita S & 0,9677 & 1,0000 \\
\hline Imelda M & 0,9140 & 0,9000 \\
\hline Al Vanesh & 0,8280 & 0,7500 \\
\hline Arum R & 1,0000 & 0,9500 \\
\hline Bobot & 0,1250 & 0,8750 \\
\hline
\end{tabular}

TABEL XXI

NILAI MATRIKS NORMALISASI SUBKRITERIA KOMPETENSI

\begin{tabular}{|c|c|c|}
\hline Alternatif & Skill & Pengetahuan \\
\hline Samuel & 0,6500 & 0,8947 \\
\hline Novita S & 0,8300 & 0,9474 \\
\hline Imelda M & 0,7500 & 1,0000 \\
\hline Al Vanesh & 1,0000 & 0,9684 \\
\hline Arum R & 0,6000 & 0,7368 \\
\hline Bobot & 0,8333 & 0,1667 \\
\hline
\end{tabular}

Dari Tabel XX dan Tabel XXI kemudian dilakukan proses perhitungan perangkingan dengan menggunakan bobot yang telah dihitung menggunakan metode AHP seperti proses sebelumnya (proses D.2) sehingga menghasilkan Tabel XXII dan XXIII.

TABEL XXII

PROSES PERANGKINGAN SUBKRITERIA PSIKOTES

\begin{tabular}{|c|c|}
\hline Alternatif & Hasil Perhitungan \\
\hline Samuel & 0,8796 \\
\hline Novita S & 0,9960 \\
\hline Imelda M & 0,9017 \\
\hline Al Vanesh & 0,7597 \\
\hline Arum R & 0,9563 \\
\hline
\end{tabular}

TABEL XXIII

Proses PERANGKINGAN SUBKRITERIA KOMPETENSI

\begin{tabular}{|c|c|}
\hline Alternatif & Hasil Perhitungan \\
\hline Samuel & 0,6908 \\
\hline Novita S & 0,8496 \\
\hline Imelda M & 0,7917 \\
\hline Al Vanesh & 0,9947 \\
\hline Arum R & 0,6228 \\
\hline
\end{tabular}

3) Perhitungan Normalisasi Matriks Kriteria

- Menghitung Nilai Normalisasi Matriks

Hasil perhitungan semua subkriteria mulai dari proses pada poin D.2, isi pada Tabel XXII dan XXIII ditulis kembali pada Tabel XXIV.

TABEL XXIV

NILAI ALTERNATIF KRITERIA

\begin{tabular}{|c|c|c|c|c|}
\hline $\mathbf{R}$ & Alternatif & Interview & Psikotes & Kompetensi \\
\hline 1 & Samuel & 0,8961 & 0,8796 & 0,6908 \\
\hline 2 & Novita Sari & 0,8238 & 0,9960 & 0,8496 \\
\hline 3 & Imelda Marcheleni & 0,9347 & 0,9017 & 0,7917 \\
\hline 4 & Al Vanesh & 0,6349 & 0,7597 & 0,9947 \\
\hline 5 & Arum Rosma & 0,9418 & 0,9563 & 0,6228 \\
\hline
\end{tabular}

Semua nilai matriks normalisasi subkriteria akan digunakan untuk nilai matriks normalisasi kriteria. Dari Tabel XXIV akan dilakukan perhitungan normalisasi matriks X pada kriteria dengan rumus (3)

- Kriteria interview

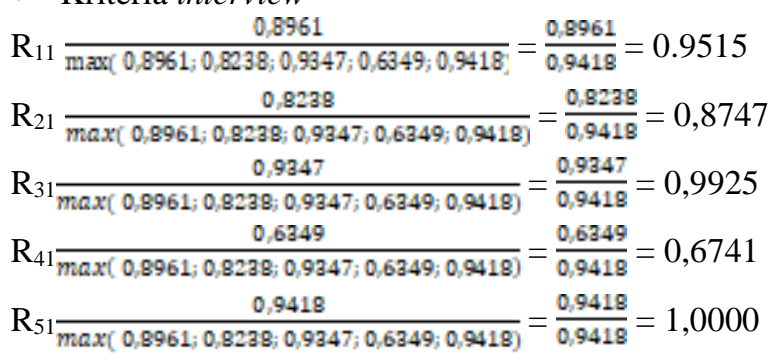

- Kriteria psikotes

$$
\begin{aligned}
& \mathrm{R} 12 \frac{0,8796}{\max \left(0,8796 ; 0,9960 ; 0,90177_{0}, 0,75975,0,9568\right)}=\frac{0,8796}{0,9960}=0,8831
\end{aligned}
$$

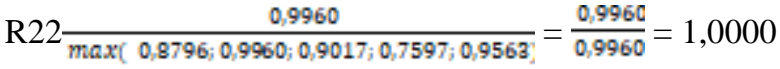

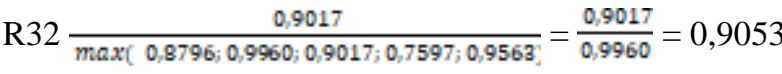

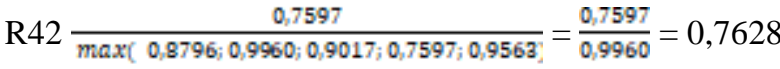

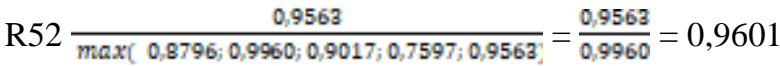


- Kriteria kompetensi

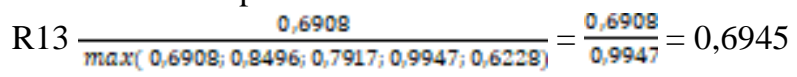

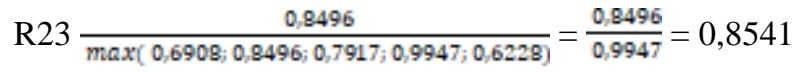

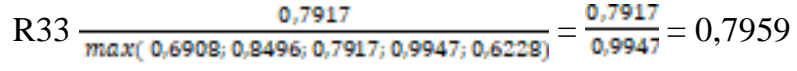

$$
\begin{aligned}
& \mathrm{R} 43 \frac{0,9947}{\max \left[0,6908_{3} 0,84966_{3} 0,7917_{i} 0,9947_{i} 0,6228\right]}=\frac{0,99477}{0,9947}=1,0000
\end{aligned}
$$

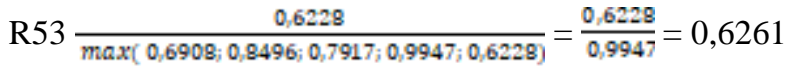

Hasil perhitungan di atas akan disimpan pada Tabel XXV.

TABEL XXV

NILAI MATRIKS NORMALISASI KRITERIA

\begin{tabular}{|c|c|c|c|c|}
\hline $\mathbf{R}$ & Alternatif & Interview & Psikotes & Kompetensi \\
\hline 1 & Samuel & 0.9515 & 0,8831 & 0,6945 \\
\hline 2 & Novita S & 0,8747 & 1,0000 & 0,8541 \\
\hline 3 & Imelda M & 0,9925 & 0,9053 & 0,7959 \\
\hline 4 & Al Vanesh & 0,6741 & 0,7628 & 1,0000 \\
\hline 5 & Arum R & 1,0000 & 0,9601 & 0,6261 \\
\hline \multicolumn{2}{|c|}{ Bobot } & $\mathbf{0 , 6 3 1 6}$ & $\mathbf{0 , 2 2 6 0}$ & $\mathbf{0 , 1 4 1 0}$ \\
\hline
\end{tabular}

- Proses Perangkingan Kriteria

Kemudian tahap selanjutnya proses perangkingan dengan menggunakan tabel XXV dan bobot yang telah dihitung menggunakan metode AHP pada Tabel XI. Berikut ini adalah ilustrasi perhitungan dengan 5 (lima) sampel dari pelamar pekerjaan.

Samuel $=\{(0,9515 \times 0,6316)+(0,8831 \times 0,2260)+(0,6945 \times 0,1$ $410)\}=0,6009+0,1996+0,0979=0,8984$

Novita $=\{(0,8747 \times 0,6316)+(1,0000 \times 0,2260)+(0,8541 \times 0,1$ $410)\}=0,5525+0,226+0,1204=0,8989$

Imelda $=\{(0,9925 \times 0,6316)+(0,9053 \times 0,2260)+(0,7959 \times 0,1$ $410)\}=0,6269+0,2046+0,1122=0,9437$

AlVanesh $=\{(0,6741 \times 0,6316)+(0,7628 \times 0,2260)+(1,0000 \mathrm{x}$ $0,1410)\}=0,4258+0,1724+0,1410=0,7392$

Arum $=\{(1,0000 \times 0,6316)+(0,9601 \times 0,2260)+(0,6261 \times 0,14$ 10) $\}=0,6316+0,2169+0,0883=0,9368$

Hasil perhitungan di atas, disimpan pada Tabel XXVI dan diurutkan secara descending menggunakan ranking.

TABEL XXVI

Hasil PERANGKINGAN NILAI DENGAN SAW

\begin{tabular}{|c|c|c|}
\hline Alternatif & Nilai & Ranking \\
\hline Imelda M & 0,9437 & 1 \\
\hline Arum R & 0,9368 & 2 \\
\hline Novita S & 0,8989 & 3 \\
\hline Samuel & 0,8984 & 4 \\
\hline Al Vanesh & 0,7392 & 5 \\
\hline
\end{tabular}

Berdasarkan nilai yang terdapat pada Tabel XXVI, pelamar dengan nilai terbesar adalah Imelda.

\section{E. Analisis Sistem Usulan}

Analisis fungsionalitas sistem akan digambarkan dengan Use Case Diagram pada gambar 7.

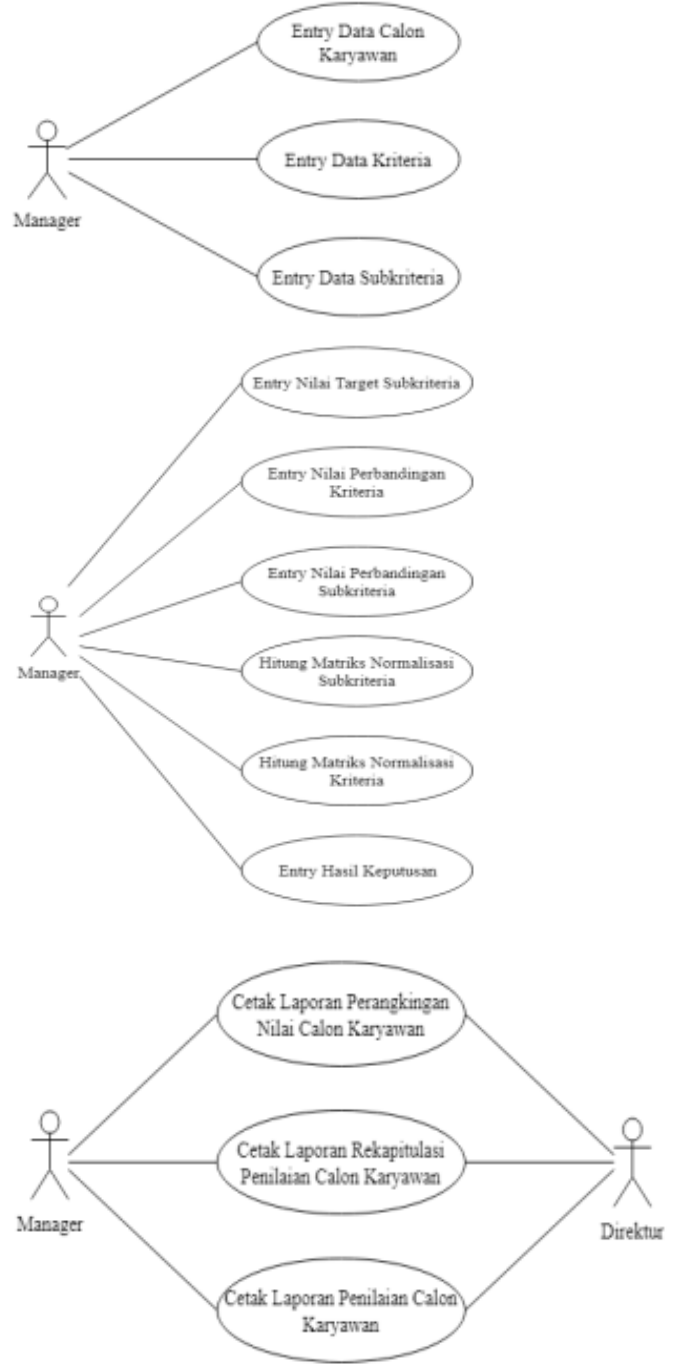

Gambar 7. Use Case Diagram SPK Rekrutmen Karyawan

\section{F. Model Data}

1) Logical Record Structure (LRS)

Analisis basis data pada SPK Rekrutmen Karyawan digambarkan menggunakan LRS pada gambar 8 .

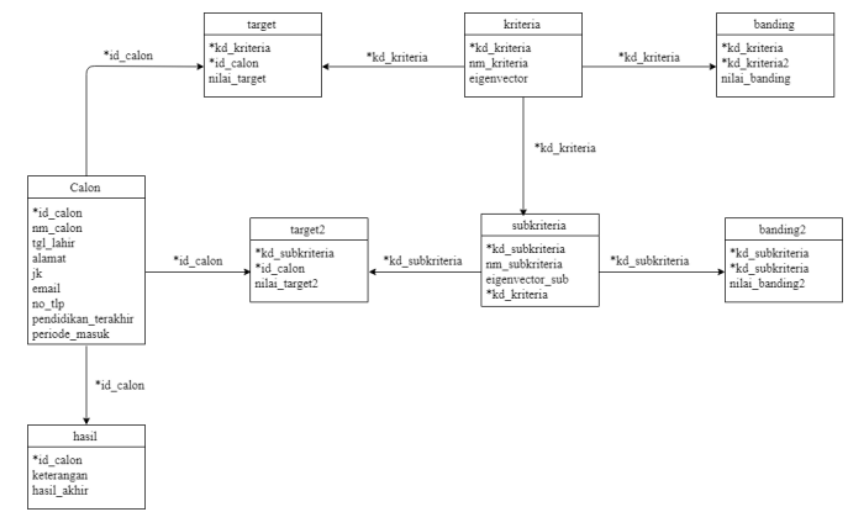

Gambar 8. LRS SPK Rekrutmen Karyawan 


\section{G. Implementasi Aplikasi}

1) Tampilan Layar Dashboard

Tampilan pada gambar 9 adalah tampilan dashboard pada sistem penunjang keputusan (SPK). Pada halaman dashboard terdapat tampilan data pelamar pekerjaan, data kriteria, dan data subkriteria dimana angka yang muncul pada tampilan adalah angka yang diambil dari total keseluruhan data yang ada pada basis data sedangkan pada menu sidebar terdapat menu data master, menu data perhitungan dan menu laporan.

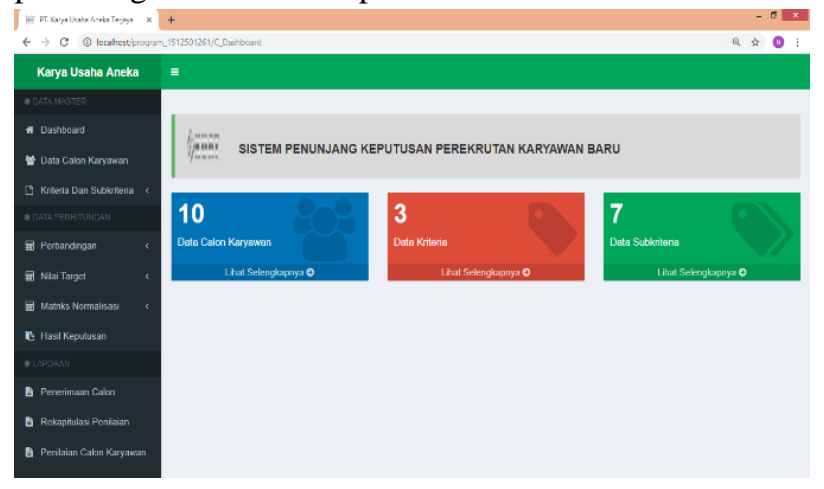

Gambar 9. Tampilan Layar Menu Dashboard

2) Tampilan Layar Entry Nilai Target Subkriteria Gambar 10 adalah tampilan form untuk menambahkan data nilai target subkriteria pelamar pekerjaan yang akan tersimpan pada tabel subkriteria. Kemudian untuk menyimpan data tekan tombol Simpan.

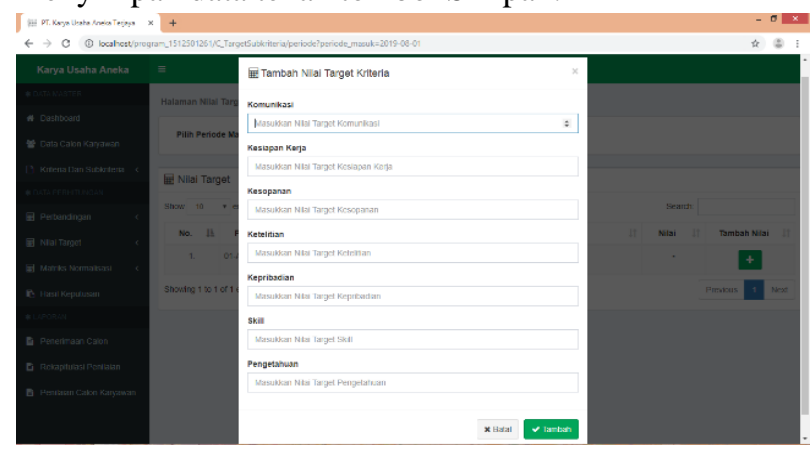

Gambar 10. Tampilan Layar Form Entry Nilai Target Subkriteria

\section{3) Tampilan Layar Grafik Hasil Perangkingan}

Gambar 11 menampilkan halaman hasil perangkingan dalam bentuk grafik, dimana pengguna harus menginput tanggal rekrutmen karyawan kemudian tekan tombol pilih. Setelah itu akan tampil data perangkingan pelamar pekerjaan dalam bentuk chart.

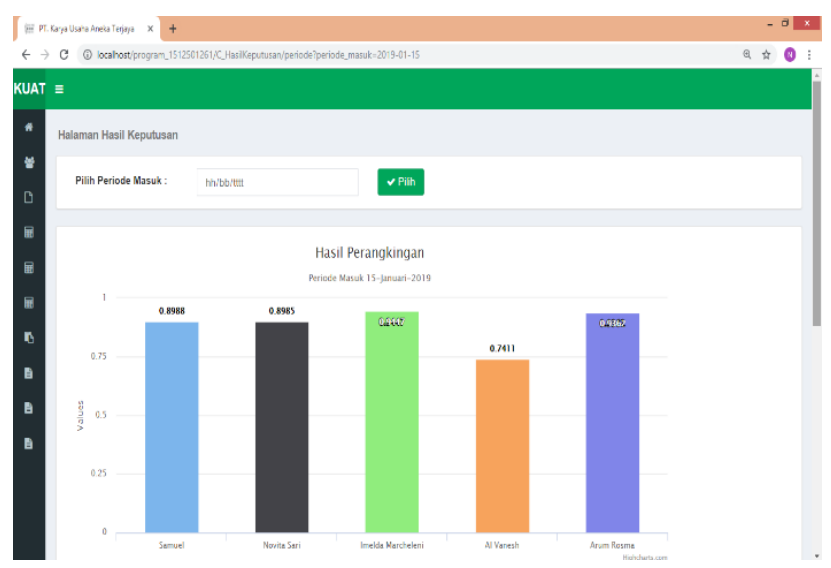

Gambar 11. Rancangan Layar Grafik Hasil Keputusan

\section{4) Tampilan Layar Entry Hasil Keputusan}

Pada gambar 12 terdapat tampilan layar entry hasil keputusan yang akan menampilkan semua kandidat pelamar pekerjaan dari hasil perhitungan menggunakan metode Simple Additive Weighting (SAW). Terdapat tombol check list yang berfungsi untuk memilih pelamar pekerjaan yang akan direkrut oleh Manager atau Direktur kemudian jika sudah memilih tekan tombol simpan.

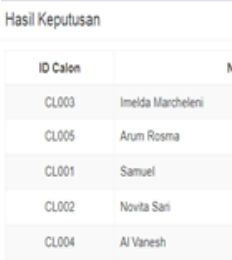

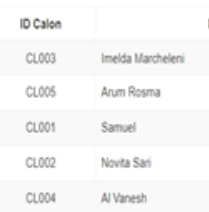

Gambar 12. Tampilan Layar Form Entry Hasil Keputusan

\section{5) Tampilan Layar Form Laporan Penerimaan Pelamar pekerjaan}

Pada gambar 13 terdapat tampilan laporan penerimaan (Rekrutmen) pelamar pekerjaan, pengguna akan menginput tanggal rekrutmen karyawan dan akan tampil identitas kandidat pelamar pekerjaan, nilai per kriteria, hasil akhir dan keterangan karyawan yang diterima atau gagal dalam proses rekrutmen.

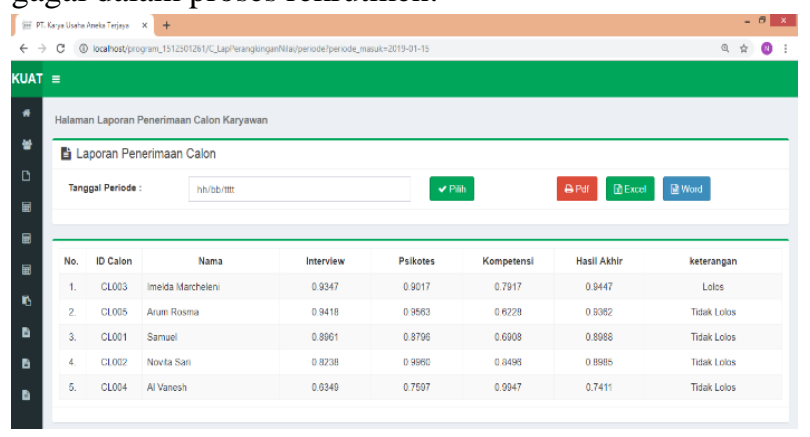

Gambar 13. Tampilan Form Laporan Penerimaan Pelamar pekerjaan

6) Tampilan Layar Form Laporan Rekapitulasi Penilaian Rekrutmen karyawan per sub kriteria 
Gambar 14 merupakan tampilan laporan rekapitulasi penilaian rekrutmen karyawan per sub kriteria. Pengguna akan menginput tanggal awal dan tanggal akhir periode laporan kemudian pengguna dapat memilih tombol cetak laporan ke bentuk pdf, excel atau word. Menu ini akan menampilkan laporan rekapitulasi penilaian berdasarkan subkriteria berdasarkan hasil akhir nilai kandidat pelamar pekerjaan.

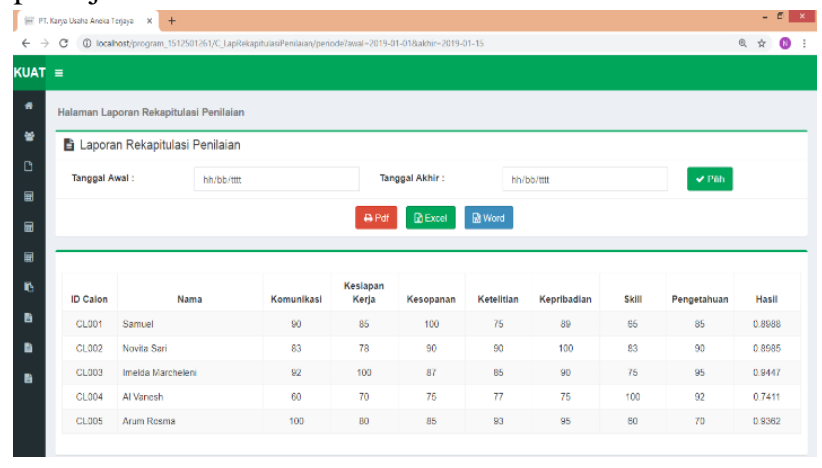

Gambar 14. Tampilan Layar Form Laporan Rekapitulasi Penilaian Rekrutmen karyawan per sub kriteria

\section{H. HASIL}

Berdasarkan Hasil pengujian yang dilakukan dengan menggunakan metode AHP dan SAW maka didapatkan hasil bahwa:

- Bobot yang didapatkan untuk kriteria adalah Interview memiliki bobot tertinggi yaitu 0,632 , Psikotes memiliki bobot tertinggi kedua yaitu 0,226, Kompetensi memiliki bobot ketiga yaitu 0,141 dengan nilai $\mathrm{CR}=0,0268$ sehingga perbandingan dianggap konsisten.

- Bobot yang didapatkan untuk subkriteria interview : Komunikasi memiliki bobot tertinggi yaitu 0,6896, kesiapan kerja 0,2327 dan kesopanan 0,0777 sedangkan Bobot yang didapatkan untuk subkriteria kompetensi: kepribadian memiliki bobot tertinggi yaitu 0,8750 dan ketelitian bobotnya 0,1250 dan Bobot yang didapatkan untuk subkriteria psikotes skill memiliki bobot tertinggi yaitu 0,8333 dan pengetahuan bobotnya 0,1667 . Nilai CR untuk subkriteria adalah 0,0946 sehingga perbandingan dianggap konsisten

- Proses perangkingan menggunakan metode SAW berhasil dilakukan, dimana pada simulasi dapat diketahui dari 5 kandidat, Imelda memiliki nilai tertinggi sehingga mendapatkan ranking 1 .

\section{KESIMPULAN}

Berdasarkan penelitian yang telah dilakukan pada PT.Karya Usaha Aneka Terjaya, maka dapat kesimpulan yang dapat diambil, yaitu:

- Dengan digunakannya metode AHP dan SAW pada sistem penunjang keputusan rekrutmen karyawan baru dapat mengurangi proses subjektifitas yang tinggi serta dapat menghasilkan nilai akhir yang akurat dalam penilaian calon karyawan.

- Implementasi SPK dengan AHP dan SAW juga membantu perusahaan dalam proses perekrutan karyawan karena proses pendataan administrasi pelamar, perhitungan serta pencetakan nilai pelamar serta pencetakan rekomendasi keputusan dilakukan dalam satu sistem sehingga pemegang keputusan dapat menentukan pilihan dengan cepat.

\section{UCAPAN TERIMA KASIH}

Terima kasih kami ucapkan kepada Universitas Budi Luhur yang telah memberikan dukungan sehingga kegiatan penelitian ini dapat terlaksana.

\section{DAFTAR PUSTAKA}

[1] CNNIndonesia, "Angka Pengangguran Naik Jadi 7,05 Juta Orang per Agustus 2019," www.cnnindonesia.com, 2019. [Online]. Available: https://www.cnnindonesia.com/ekonomi/20191105154437 -532-445788/angka-pengangguran-naik-jadi-705-jutaorang-per-agustus-2019. [Accessed: 12-Feb-2019].

[2] Badan Pusat Statistik, "Keadaan Tenagakerjaan Indonesia Februari 2020,” Jakarta, 40/05/th/XXIII, 2020.

[3] D. N. Utama, Sistem Penunjang Keputusan: Filosofi Teori dan Implementasi. Yogyakarta: Garudhawaca, 2017.

[4] D. Nofriansyah, Konsep Data Mining VS Sistem Pendukung Keputusan. Yogyakarta: DEEPUBLISH, 2014.

[5] A. Rikki, M. Marbun, and J. R. Siregar, "Sistem Pendukung Keputusan Penerimaan Karyawan Dengan Metode SAW Pada PT. Karya Sahata Medan," J. Informatics Pelita Nusant., vol. 1, no. 1, pp. 38-46, 2016.

[6] R. Taufiq, A. A. Permana, T. Cahyanto, and R. Adha, "Sistem Pendukung Keputusan Penerimaan Karyawan Menggunakan Simple Additive Weighting Studi Kasus PT. Trafoindo Prima Perkasa," J. Al-AZHAR Indones. SERI SAINS DAN Teknol., vol. 4, no. 4, pp. 186-194, 2018.

[7] Yupianti and S. P. Sari, "Sistem Pendukung Keputusan Penerimaan Karyawan Menggunakan Metode SAW (Studi Kasus di PT.Nusantara Sakti Ciptadana Finance Kota Bengkulu),” J. Media Infotama, vol. 13, no. 2, pp. 55-66, 2017.

[8] M. F. Penta, F. B. Siahaan, and S. H. Sukmana, "Sistem Pendukung Keputusan Pemilihan Karyawan Terbaik Menggunakan Metode SAW pada PT. Kujang Sakti Anugrah,” JSAI (Journal Sci. Appl. Informatics), vol. 2, no. 3, pp. 185-192, 2019.

[9] B. Rianto, "Sistem Pendukung Keputusan Penerimaan Karyawan Menggunakan Metode Analytical Hierarchy Process (AHP) Studi Kasus: RB . Nilam Sari Tembilahan," Riau J. Comput. Sci., vol. 2, no. 2, pp. 2938, 2016.

[10] Muzdalifah and S. Juanita, "Sistem Penunjang Keputusan Terbaik Menggunakan Metode Analytical Hierarchy Process Dan Simple Additive Weighting Studi Kasus: PT.Gading Murni Cabang Jakarta," Idealis, vol. 2, no. 5, pp. 289-297, 2019. 
[11] A. M. Pratama and Rusdah, "Penerapan Metode Analytical Hierarchy Process Untuk Pemilihan Karyawan Terbaik Pada PT . Radio ELSHINTA,” IDEALIS, vol. 3, no. 1, pp. 386-391, 2020.

[12] A. Dennis, B. H. Wizom, and R. M. Roth, System Analysis \& Design, 5th ed. USA: John Wiley \& Sons, 2012.

[13] M. Coccia, "The fishbone diagram to identify, systematize and analyze the sources of general purpose technologies," J. Soc. Adm. Sci., vol. 2, no. 2, pp. 53-61, 2017.

[14] R. W. Saaty, "The analytic hierarchy process-what it is and how it is used," Math. Model., vol. 9, no. 3-5, pp. 161$176,1987$. 